Article

\title{
Spirulina maxima Extract Reduces Obesity through Suppression of Adipogenesis and Activation of Browning in 3T3-L1 Cells and High-Fat Diet-Induced Obese Mice
}

\author{
Young-Jin Seo ${ }^{\dagger}$, Kui-Jin Kim ${ }^{\dagger}$, Jia Choi, Eun-Jeong Koh and Boo-Yong Lee * \\ Department of Food Science and Biotechnology, College of Life Science, CHA University, Seongnam, \\ Kyeonggi 463-400, Korea; youngjinseo92@gmail.com (Y.-J.S.); kuijin.kim@gmail.com (K.-J.K.); \\ wldk3176@gmail.com (J.C.); kej763@naver.com (E.-J.K.) \\ * Correspondence: bylee@cha.ac.kr; Tel.: +82-31-881-7155 \\ † These authors contributed equally to this work.
}

Received: 8 May 2018; Accepted: 31 May 2018; Published: 1 June 2018

\begin{abstract}
Obesity predisposes animals towards the metabolic syndrome and diseases such as type 2 diabetes, atherosclerosis, and cardiovascular disease. Spirulina maxima is a microalga with anti-oxidant, anti-cancer, and neuroprotective activities, but the anti-obesity effect of Spirulina maxima $70 \%$ ethanol extract (SM70EE) has not yet been fully established. We investigated the effect of SM70EE on adipogenesis, lipogenesis, and browning using in vitro and in vivo obesity models. SM70EE treatment reduced lipid droplet accumulation by the oil red $\mathrm{O}$ staining method and downregulated the adipogenic proteins $\mathrm{C} / \mathrm{EBP} \alpha, \operatorname{PPAR} \gamma$, and $\mathrm{aP2}$, and the lipogenic proteins SREBP1, ACC, FAS, LPAAT $\beta$, Lipin1, and DGAT1 by western blot analysis. In addition, the index components of SM70EE, chlorophyll a, and C-phycocyanin, reduced adipogenesis and lipogenesis protein levels in 3T3-L1 and C3H10T1/2 cells. High-fat diet (HFD)-fed mice administered with SM70EE demonstrated smaller adipose depots and lower blood lipid concentrations than control HFD-fed mice. The lower body mass gain in treated SM70EE-administrated mice was associated with lower protein expression of adipogenesis factors and higher expression of AMPK $\alpha$-induced adipose browning proteins PRDM16, PGC1 $\alpha$, and UCP1. SM70EE administration ameliorates obesity, likely by reducing adipogenesis and activating the thermogenic program, in 3T3-L1 cells and HFD-induced obese mice.
\end{abstract}

Keywords: obesity; Spirulina maxima; adipogenesis; browning; 3T3-L1 cells; HFD-induced obese mice

\section{Introduction}

Obesity is one of the leading preventable causes of death and is becoming an increasingly serious social problem worldwide. Obesity can lead to metabolic disease, including hypertension, type 2 diabetes, hyperlipidemia, and arteriosclerosis [1], and is caused by an imbalance between energy intake and expenditure in adipose tissue [2]. There are two distinct types of adipose tissue in mammals: white adipose tissue (WAT) and brown adipose tissue (BAT). WAT stores excess energy in the form of triglyceride (TG), which can be lipolyzed to liberate glycerol and free fatty acids [3]. BAT specializes in energy expenditure through induction of uncoupling protein 1 (UCP1) expression [4,5]. Recently, it was established that UCP1 can be expressed in WAT adipocytes that are referred to as 'beige' or 'brite (brown-in-white)', representing 'inducible BAT' [6]. These adipocytes undergo a browning process, which converts preadipocytes into beige adipocytes [7], which also play a crucial role in the regulation of energy. 
Adipogenesis is the cellular differentiation process that transforms preadipocytes into mature adipocytes, involving dramatic changes in adipocyte morphology, and which can be artificially induced using 3-isobutyl-1-methylxanthine (IBMX), dexamethasone, and insulin. Many transcription factors regulate this process, including CCAAT/enhancer-binding protein alpha $(\mathrm{C} / \mathrm{EBP} \alpha)$, peroxisome proliferator-activated receptor gamma (PPAR $\gamma$ ), and adipocyte protein 2 (aP2) [8]. In addition, lipogenic related enzymes, such as fatty acid synthase (FAS) and diacylglycerol acyltransferases (DGAT), play important roles in lipid accumulation during adipogenesis [9]. High expression levels of lipogenic genes, such as acetyl-CoA carboxylase (ACC), FAS, lysophosphatidic acid acyltransferase (LPAAT), lipin, and DGAT enhance adipogenesis and obesity [10-12], whereas LPAAT $\beta$ and lipin1-deficient cells do not express adipogenic marker proteins, such as C/EBP $\alpha$ and PPAR $\gamma$, during adipocyte differentiation $[13,14]$.

AMP-activated protein kinase alpha (AMPK $\alpha$ ) activation has been suggested to inhibit adiposity, reducing expression of C/EBP $\alpha$ and PPAR $\gamma$ in 3T3-L1 cells and high-fat diet (HFD)-induced obese mice $[15,16]$. AMPK $\alpha$ is induced by an increase in the cellular AMP/ATP ratio, which regulates energy production or consumption. Recently, studies have revealed that AMPK $\alpha$ can directly interact with PPAR $\gamma$ coactivator 1 alpha (PGC1 $\alpha$ ) [17], which has been shown to be necessary for mitochondrial and thermogenic activity [18]. Thermogenesis is induced by brown adipocyte-specific markers, including PR domain containing 16 (PRDM16), PGC1 $\alpha$, and UCP1 [7].

It has also been reported that a variety of phytochemicals can affect body weight, adipocyte differentiation, and the conversion of white fat cells to brown or beige adipocytes [19]. Spirulina maxima is a microalga that is rich in essential nutrients and contains pigment proteins such as chlorophyll a and C-phycocyanin [20-23]. Several reports have proposed that chlorophyll a and C-phycocyanin are index components of Spirulina maxima [24,25]. Recently, many studies have demonstrated that Spirulina maxima has anti-oxidant, anti-cancer, and neuroprotective properties $[20,26,27]$. An index compound of Spirulina maxima, chlorophyll a, has anti-oxidant and anti-inflammatory activities [28], while a second, C-phycocyanin, has anti-oxidant, anti-inflammatory, and anti-diabetic potential [29,30]. However, it is not known whether Spirulina maxima has anti-obesity effects. The aim of this study was to investigate the anti-obesity and browning effects of Spirulina maxima 70\% ethanol extract (SM70EE) in vitro and in vivo. In addition, we investigated whether chlorophyll a and C-phycocyanin have effects as index components on adipogenesis in vitro. We show that Spirulina maxima extracts can ameliorate obesity-related markers by modulating adipogenesis and browning of adipocyte.

\section{Materials and Methods}

\subsection{Experimental Materials}

SM70EE was acquired from the Korea Institute of Ocean Science \& Technology, where it was produced by a two-phase method of extraction. In the first step, Spirulina maxima was ultrasound-extracted in $70 \%$ ethanol at room temperature for $\sim 8 \mathrm{~h}$. The product was then extracted at $65-70{ }^{\circ} \mathrm{C}$ for $\sim 4 \mathrm{~h}$ and the extract was analyzed [24]. The composition of SM70EE are shown in Table 1. Chlorophyll a was purchased from Toronto Research Chemicals (Toronto, ON, Canada) and C-phycocyanin was acquired from Xi'an Day Natural Inc. (Pudong, Shanghai, China). The chlorophyll a and C-phycocyanin content of the SM70EE was quantified by high-performance liquid chromatography photo-diode array (HPLC-PDA) analysis, as previously described [24]. The chlorophyll a and C-phycocyanin are contained in SM70EE at approximately 5\% and 10\%, respectively. Dulbecco's modified Eagle's medium (DMEM), bovine calf serum (BCS), fetal bovine serum (FBS), penicillin-streptomycin (P/S), insulin, and trypsin-EDTA were purchased from Gibco (Gaithersburg, MD, USA). Dexamethasone, isopropanol, oil red O, and chemical reagents were mainly purchased from Sigma-Aldrich (St Louis, MO, USA). Primary antibodies specific for C/EBP $\alpha$, PPAR $\gamma$, aP2, SREBP1, ACC, FAS, LPAAT $\beta$, Lipin1, DGAT1, PGC1 $\alpha, \alpha$-tubulin, GAPDH 
(Santa Cruz Biotechnology, Dallas, TX, USA), p-AMPK $\alpha$ (Cell signaling, Beverly, MA, USA), PRDM16, and UCP1 (Abcam, Cambridge, UK) were purchased.

Table 1. Composition of SM70EE.

\begin{tabular}{cc}
\hline Components & SM70EE (\%) \\
\hline Carbohydrate & 23.51 \\
Crude proetin & 59.94 \\
Crude fat & 4.16 \\
Crude ash & 10.01 \\
Moisture & 2.38 \\
\hline
\end{tabular}

\subsection{Cell Culture}

Mouse 3T3-L1 preadipocytes and C3H10T1/2 cells were obtained from the ATCC (Manassas, VA, USA) and were maintained in DMEM containing $10 \%$ BCS and $1 \%$ penicillin/streptomycin (P/S) at $37{ }^{\circ} \mathrm{C}$ in a $5 \% \mathrm{CO}_{2}$ incubator. To induce adipogenesis, $\mathrm{C} 3 \mathrm{H} 10 \mathrm{~T} 1 / 2$ cells were incubated in DMEM and BMP4 $(10 \mu \mathrm{g} / \mathrm{mL})$ for $\sim 3$ days, until they became confluent. After this, the preadipocytes were cultured in DMEM containing 10\% FBS, $0.5 \mathrm{mM}$ IBMX, $1 \mu \mathrm{M}$ dexamethasone, and $4 \mu \mathrm{g} / \mathrm{mL}$ insulin for 2 days. To stimulate browning of adipocytes, the differentiation medium was supplemented with $50 \mathrm{nM}$ triiodothyronine and $1 \mu \mathrm{M}$ rosiglitazone for 2 days. The adipocyte culture medium consisted of DMEM containing 10\% FBS and $4 \mu \mathrm{g} / \mathrm{mL}$ insulin, and was changed every 2 days.

\subsection{Cell Viability Assay}

3T3-L1 preadipocytes ( $10^{4}$ cells / well) were incubated in DMEM containing $10 \%$ BCS overnight in 96-well plates. The cells were then treated with $\operatorname{SM70EE}(0,6.25,12.5,25,50,100$, or $200 \mu \mathrm{g} / \mathrm{mL})$, chlorophyll a, or C-phycocyanin $(0,0.625,1.25,2.5,5,10$, or $20 \mu \mathrm{g} / \mathrm{mL})$ for $24 \mathrm{~h}$. Twenty microliters of MTT solution was added to each well and the cells were incubated at $37{ }^{\circ} \mathrm{C}$ for a further $3 \mathrm{~h}$. Then, the MTT-containing media was gently aspirated, and $100 \mu \mathrm{L}$ DMSO was added to extract intracellular formazans, which were quantified by ELISA, using a Wallac 140 Victor spectrophotometer (Perkin Elmer, Boston, MA, USA) at $570 \mathrm{~nm}$.

\subsection{Oil Red O Staining}

Differentiated 3T3-L1 adipocytes were fixed with 10\% formalin in PBS for $1 \mathrm{~h}$ and washed twice with $60 \%$ isopropanol. The fixed cells were then stained using oil red $\mathrm{O}$ solution for $30 \mathrm{~min}$ and washed with distilled water. After drying, the fixed cells were imaged by scanner. The oil red O solution taken up by the cells was then extracted using $100 \%$ isopropanol and its optical intensity was measured at $490 \mathrm{~nm}$.

\subsection{Animal Studies}

Male ICR mice were purchased from Orient Bio Co. (Gapyeong, Kyeonggi, Korea) at 4 weeks of age. The animal study was approved by the Institutional Animal Care and Use Committee (IACUC) of CHA University (Approval Number 170091). Mice were kept under temperature and humidity-controlled conditions at a $12 \mathrm{~h}$ light/dark cycle. After a 1-week acclimation period, they were fed a chow diet (Envigo, Huntingdon, Cambridgeshire, UK), a $60 \mathrm{kcal} \%$ fat HFD (Central Lab Animal Inc., Seoul, Korea), or a HFD supplemented with SM70EE for 6 weeks (Table 2). The vehicle of the CHOW and HFD group administered SM70EE $0 \mathrm{mg} / \mathrm{kg} /$ day. During the experiment, body mass, fasting blood glucose, and food intake were measured weekly. After this period, the mice were starved overnight and euthanized, and blood and tissue samples were collected. 
Table 2. Composition of CHOW diet and HFD.

\begin{tabular}{ccc}
\hline \multirow{2}{*}{ Ingredient } & \multicolumn{2}{c}{ Group } \\
\cline { 2 - 3 } & CHOW (kcal\%) & HFD (kcal\%) \\
\hline Carbohydrate & 58 & 20 \\
Proetin & 24 & 20 \\
Fat & 18 & 60 \\
\hline
\end{tabular}

\subsection{Blood Parameter Analysis}

Mice were sacrificed by $\mathrm{CO}_{2}$ asphyxiation. Blood was collected by cardiac puncture and placed into blood collecting tubes aseptically. To collect serum, blood was coagulated for $1 \mathrm{~h}$ at room temperature and then centrifuged at $13,000 \times \mathrm{g}$ for $15 \mathrm{~min}$ at $4{ }^{\circ} \mathrm{C}$. Serum levels of TG, total cholesterol, low-density lipoprotein (LDL)-cholesterol, and high-density lipoprotein (HDL)-cholesterol were measured using kits supplied by Roche (Mannheim, Germany) using the manufacturers' protocols.

\subsection{Preparation of the Stromal Vascular Fraction}

Stromal vascular fractions (SVFs) were isolated by digestion of subcutaneous adipose tissue from C57BL/ 6 mice for $1 \mathrm{~h}$ in PBS containing $10 \mathrm{mM} \mathrm{CaCl}_{2}, 1.5$ units $/ \mathrm{mL}$ collagenase $\mathrm{D}$, and 2.4 units $/ \mathrm{mL}$ dispase. The process was stopped by the addition of DMEM/F12 containing $10 \%$ FBS, and the digest was then filtered through a 70- $\mu \mathrm{m}$ cell strainer. The cell suspension was then seeded into $10 \mathrm{~cm}$ plates, and after $2 \mathrm{~h}$ the medium was changed to remove red blood cells and other residues. Differentiation of the isolated SVF cells was then induced using an induction medium, as described previously [31].

\subsection{Western Blotting}

Cells and tissues were lysed in lysis buffer (iNtRON Biotechnology Inc., Seoul, Korea) containing protease and phosphatase inhibitors (Sigma-Aldrich). Protein concentration was determined using a Bradford assay kit (Bio-Rad Laboratories, Hercules, CA, USA). Equal amounts of protein were separated by sodium dodecyl sulfate- $8-12 \%$ polyacrylamide gel electrophoresis and transferred to polyvinylidene fluoride membranes. After blocking with $5 \%$ skim milk for $1 \mathrm{~h}$ at room temperature, the membranes were incubated with primary antibodies overnight at $4{ }^{\circ} \mathrm{C}$, followed by incubation with horseradish peroxidase-conjugated secondary antibodies (1: 5000) for $2 \mathrm{~h}$ at room temperature. Finally, protein bands were visualized with an enhanced chemiluminescence solution and analyzed using a Chemi-doc (Bio-Rad Laboratories).

\subsection{Statistical Analysis}

Data are presented as mean \pm standard deviation (SD). One-way ANOVA with Duncan's test was used to assess differences between groups (SPSS, Chicago, IL, USA). $p<0.05$ was regarded as representing statistical significance, and for multiple comparisons, statistical differences among the groups are indicated below using ' $a, b, c$, and $d$ '.

\section{Results}

\subsection{SM70EE, Chlorophyll a, and C-Phycocyanin Inhibit Lipid Accumulation in 3T3-L1 Cells}

To evaluate the cytotoxicity of SM70EE and index components chlorophyll a and C-phycocyanin, we performed an MTT assay in 3T3-L1 preadipocytes. As shown in Figure 1a, SM70EE at $200 \mu \mathrm{g} / \mathrm{mL}$ impaired cell viability; therefore, 50 and $100 \mu \mathrm{g} / \mathrm{mL}$ SM70EE were used in further investigations. We also showed that chlorophyll a and C-phycocyanin have no significant cytotoxicity when administered at up to $10 \mu \mathrm{g} / \mathrm{mL}$ to mice.

To evaluate the effects of SM70EE, chlorophyll a, and C-phycocyanin, 3T3-L1 cells were cultured in adipocyte differentiation media for 8 days in the presence or absence of SM70EE, chlorophyll a, 
or C-phycocyanin. We then undertook oil red O staining and western blot analysis to assess their effects on adipogenic differentiation. As shown in Figure 1b, SM70EE had a dose-dependent effect to reduce oil red O staining versus that of control 3T3-L1 cells. Chlorophyll a and C-phycocyanin reduced lipid droplet accumulation in 3T3-L1 adipocytes compared to control differentiated adipocytes. As shown in Figure 1c,d, SM70EE, chlorophyll a, and C-phycocyanin blocked expression of the differentiation-induced proteins including $\mathrm{C} / \mathrm{EBP} \alpha, \mathrm{PPAR} \gamma$, and aP2 during 3T3-L1 differentiation. However, SM70EE suppressed the expression of late stage adipogenic regulators more profoundly than chlorophyll a and C-phycocyanin in these cells.

a

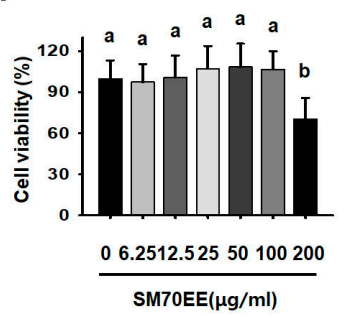

b

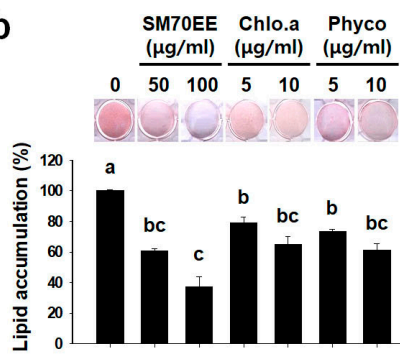

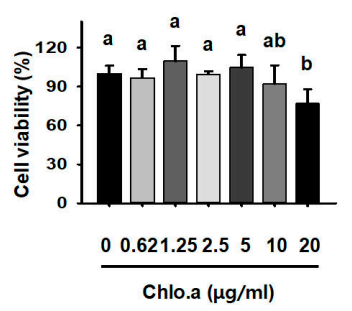
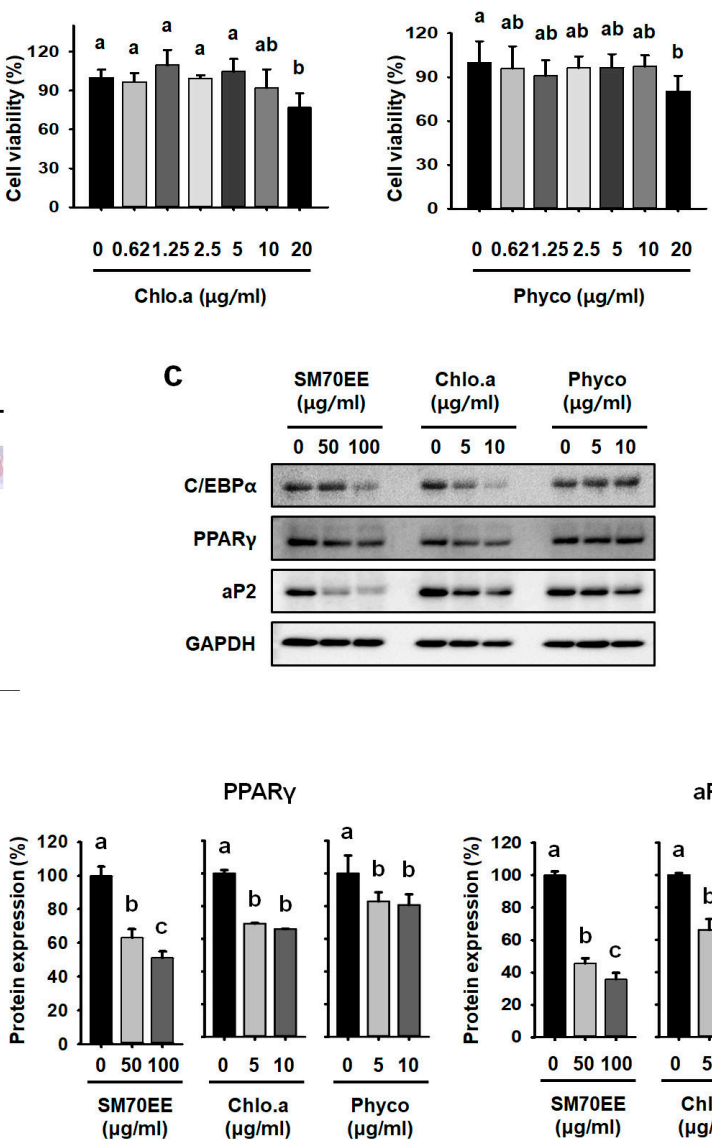

C/EBPa

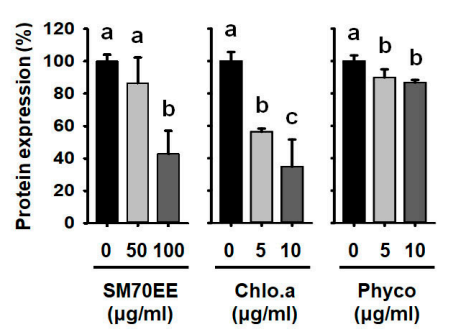

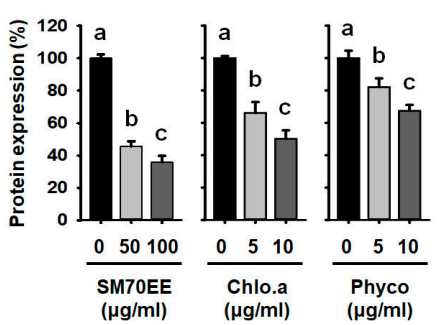

Figure 1. SM70EE, chlorophyll a, and C-phycocyanin inhibit adipogenic differentiation in 3T3-L1 cell. (a) Effect of SM70EE, chlorophyll a, and C-phycocyanin on cell viability in 3T3-L1 preadipocytes, determined using a 24-h MTT assay. (b) Effect of SM70EE, chlorophyll a, and C-phycocyanin on lipid accumulation, determined using oil red $\mathrm{O}$ staining, in 3T3-L1 adipocytes. A differentiation-inducing cocktail with or without SM70EE, chlorophyll a, or C-phycocyanin was added to 3T3-L1 adipocytes for 8 days. (c) Western blot analysis of adipogenic markers (C/EBP $\alpha, \operatorname{PPAR} \gamma$, and aP2) after 8 days of incubation of 3T3-L1 adipocytes in differentiation medium. (d) The specific bands in (c) were quantified and are presented as graphs. Data are expressed as mean $\pm \operatorname{SD}(n=3)$. Values with different letters are significantly different, $p<0.05(\mathrm{a}>\mathrm{b}>\mathrm{c})$.

\subsection{SM70EE, Chlorophyll $a$, and C-Phycocyanin Regulate Lipogenesis Pathway Enzymes in 3T3-L1 cells}

To elucidate the mechanisms of the lipogenic effect of SM70EE, chlorophyll a, and C-phycocyanin, we analyzed the expression levels of the lipogenic genes SREBP-1c, ACC, FAS, LPAAT $\beta$, lipin1, and DGAT1 by western blotting. Culture in differentiation media enhanced the expression of SREBP-1C, its downstream target, PPAR $\gamma$, and the lipogenic enzymes ACC and FAS in adipocytes [32,33]. As shown in Figure 2a, protein levels of SREBP1, ACC, and FAS were lower in the presence of 
SM70EE. Consistent with the above data, addition of the SM70EE index compounds chlorophyll a or C-phycocyanin dramatically reduced the expression of the lipogenic markers LPAAT $\beta$, lipin1, and DGAT1 (Figure 2b). Taken together, our data show that SM70EE, chlorophyll a, and C-phycocyanin significantly suppress lipogenesis by reducing lipogenic gene expression during the differentiation of 3T3-L1 cells.
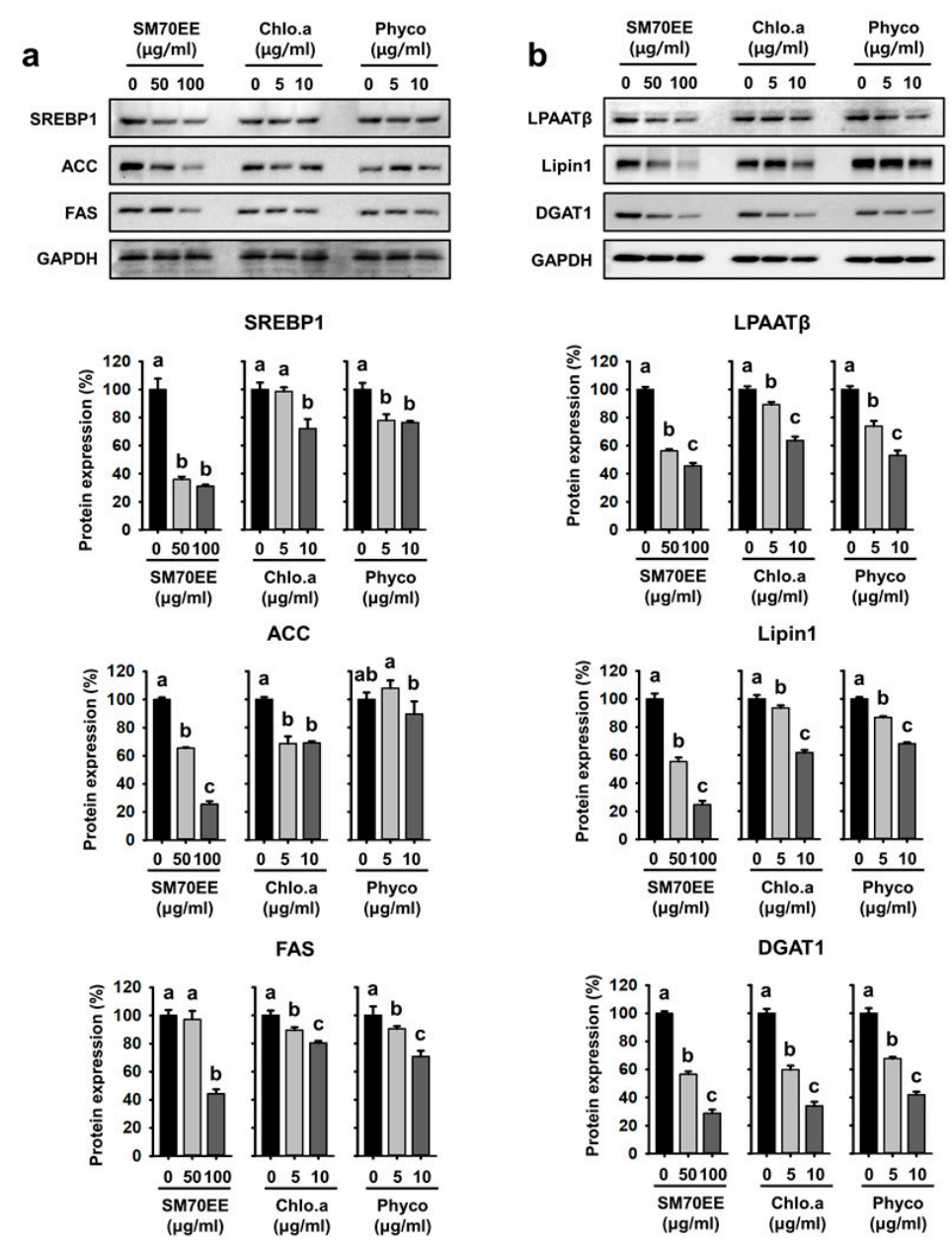

Figure 2. SM70EE, chlorophyll a, and C-phycocyanin regulate lipogenesis pathway enzyme expression in 3T3-L1 cells. (a) Western blots of SREBP1, ACC, and FAS protein expression after differentiation for 8 days. Specific bands were quantified and these are presented as graphs. (b) Representative western blots of lipogenic proteins (LPAAT $\beta$, lipin1, and DGAT1) in 3T3-L1 adipocytes. Data are expressed as mean $\pm \mathrm{SD}(n=3)$. Values with different letters are significantly different, $p<0.05(\mathrm{a}>\mathrm{b}>\mathrm{c})$.

\subsection{SM7OEE, Chlorophyll a, and C-Phycocyanin Reduce the Expression of Markers of Adipogenesis and Lipogenesis in C3H10T1/2 Cells}

We next aimed to establish whether SM70EE reduces the expression of markers of adipogenesis and lipogenesis in C3H10T1/2 cells, as well as in 3T3-L1 cells. As shown in Figure 3a, the addition of SM70EE, chlorophyll a, or C-phycocyanin resulted in lower protein expression of the adipogenic factors $\mathrm{C} / \mathrm{EBP} \alpha, \mathrm{PPAR} \gamma$, and aP2 than MDI treatment alone in $\mathrm{C} 3 \mathrm{H} 10 \mathrm{~T} 1 / 2$ cells. As shown in Figure $3 \mathrm{~b}$, SM70EE addition in particular was associated with lower expression of the lipogenic proteins LPAAT $\beta$, lipin1, and DGAT1, but addition of chlorophyll a and C-phycocyanin also tended to have the same effect. Thus, these substances had similar effects in C3H10T1/2 cells to those observed in 3T3-L1 cells. 
a

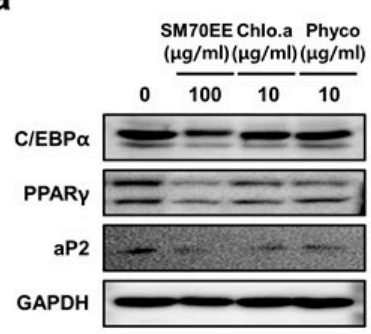

b

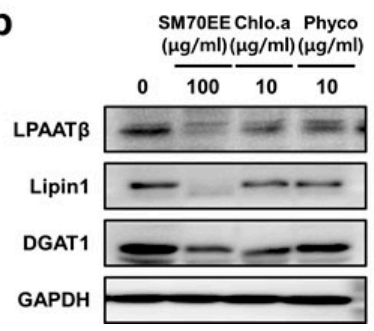

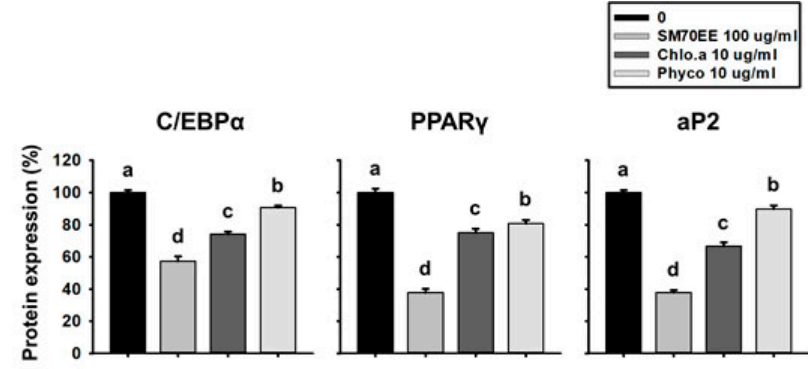

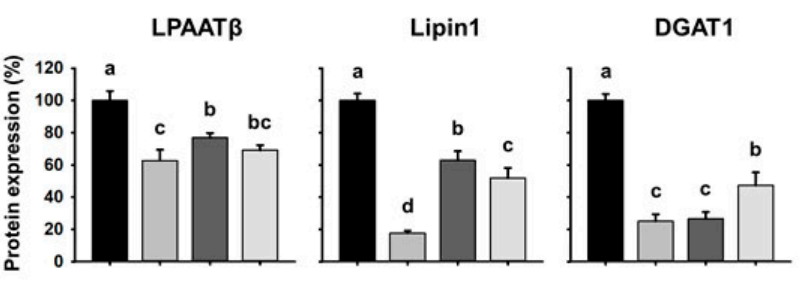

Figure 3. SM70EE, chlorophyll a, and C-phycocyanin reduce the expression of adipogenic and lipogenic proteins in $\mathrm{C} 3 \mathrm{H} 10 \mathrm{~T} 1 / 2$ cells. (a) Western blots of adipogenic protein $(\mathrm{C} / \mathrm{EBP} \alpha, \mathrm{PPAR} \gamma$, and aP2) expression after differentiation for 8 days. Quantification graphs for $\mathrm{C} / \mathrm{EBP} \alpha, \operatorname{PPAR} \gamma$, and aP2 expression. (b) Western blots of lipogenic protein (SREBP1, LPAAT $\beta$, Lipin1, and DGAT1) expression in C3H10T1/2 cells. The specific bands were quantified and are presented as graphs. Data are expressed as mean $\pm \mathrm{SD}(n=3)$. Values with different letters are significantly different, $p<0.05(\mathrm{a}>\mathrm{b}>\mathrm{c})$.

\subsection{SM70EE Reduces Adiposity in HFD-Induced Obese Mice}

To establish whether the inhibitory effects of SM70EE on lipogenesis and adipogenesis in vitro also occur in vivo, we analyzed their effects on the WAT of HFD-induced obese mice. Representative images of the mice are shown in Figure $4 \mathrm{a}$.
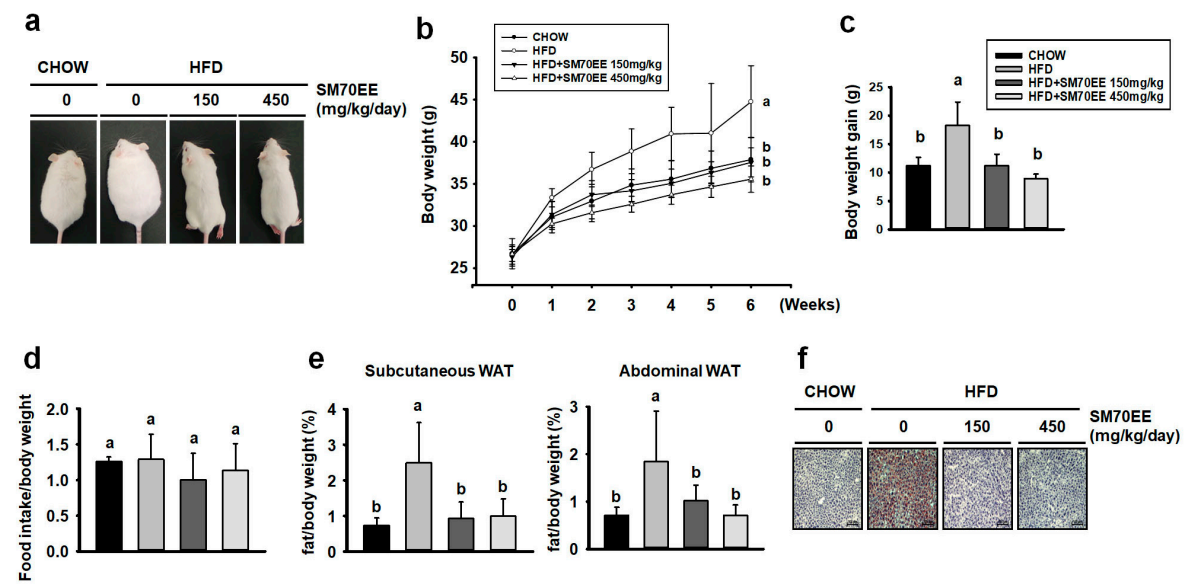

Figure 4. SM70EE ameliorates obesity in HFD-fed mice. (a) Representative image of the whole body. The effects of SM70EE on body mass (b), body mass gain (C), and food intake per unit body mass (d) were monitored for 6 weeks during treatment with SM70EE. (e) The mass of subcutaneous and abdominal fat depots per unit body mass are shown as graphs. (f) The effect of SM70EE on hepatic lipogenesis was assessed using oil red $\mathrm{O}$ staining. Mice were or were not administered with SM70EE (150 or $450 \mathrm{mg} / \mathrm{kg} /$ day) in their HFD for 6 weeks. Data are expressed as mean $\pm \operatorname{SD}(n=6)$. Values with different letters are significantly different, $p<0.05(\mathrm{a}>\mathrm{b})$. 
In control HFD-induced obese mice, body mass rose from $26 \mathrm{~g}$ to $45 \mathrm{~g}$ over the 6 weeks of the study, but the mass gain was significantly less in SM70EE-treated HFD-fed mice (Figure 4b). From 1 week, the body weight of SM70EE-fed mice began to be significantly reduced compared with HFD-fed mice. As shown in Figure 4c, the body mass gain of HFD-fed mice treated with SM70EE was similar to that of chow-fed mice over this period. There was no difference in food consumption among the groups, suggesting that the reduction in body mass gain in SM70EE-treated mice was not due to lower food intake (Figure 4d). To clarify whether the suppression of weight gain caused by SM70EE was due to the accumulation of less adipose tissue, individual adipose depot masses were measured. As shown in Figure 4e, subcutaneous and abdominal WAT depot masses were lower in SM70EE-treated HFD-fed mice than in HFD-fed control mice. By contrast, there were no differences in the masses of other organs among the groups (Table 3).

Table 3. Effect of SM70EE administration on organ weight in HFD-fed obese mice for 6 weeks.

\begin{tabular}{ccccc}
\hline \multirow{2}{*}{ Variables/Groups } & \multicolumn{4}{c}{ Organ Weight (g) } \\
\cline { 2 - 5 } & CHOW & HFD \\
\cline { 2 - 5 } & SM70EE 0 * & SM70EE 0 * $^{*}$ SM70EE 150 * $^{*}$ & SM70EE 450 * $^{*}$ \\
\hline Subcuteneous WAT & $0.29 \pm 0.14^{\mathrm{b}}$ & $0.91 \pm 0.46^{\mathrm{a}}$ & $0.38 \pm 0.15^{\mathrm{b}}$ & $0.33 \pm 0.16^{\mathrm{b}}$ \\
Abdominal WAT & $0.32 \pm 0.15^{\mathrm{b}}$ & $1.66 \pm 0.88^{\mathrm{a}}$ & $0.34 \pm 0.19^{\mathrm{b}}$ & $0.38 \pm 0.17^{\mathrm{b}}$ \\
Liver & $1.55 \pm 0.12^{\mathrm{a}}$ & $1.47 \pm 0.22^{\mathrm{a}}$ & $1.42 \pm 0.11^{\mathrm{a}}$ & $1.38 \pm 0.13^{\mathrm{a}}$ \\
Heart & $0.21 \pm 0.03^{\mathrm{a}}$ & $0.19 \pm 0.03^{\mathrm{a}}$ & $0.19 \pm 0.02^{\mathrm{a}}$ & $0.18 \pm 0.02^{\mathrm{a}}$ \\
Lung & $0.20 \pm 0.03^{\mathrm{a}}$ & $0.22 \pm 0.02^{\mathrm{a}}$ & $0.22 \pm 0.05^{\mathrm{a}}$ & $0.22 \pm 0.02^{\mathrm{a}}$ \\
Kidney & $0.62 \pm 0.06^{\mathrm{a}}$ & $0.6 \pm 0.04^{\mathrm{a}}$ & $0.55 \pm 0.07^{\mathrm{a}}$ & $0.60 \pm 0.05^{\mathrm{a}}$ \\
Spleen & $0.21 \pm 0.29^{\mathrm{a}}$ & $0.12 \pm 0.02^{\mathrm{a}}$ & $0.1 \pm 0.03^{\mathrm{a}}$ & $0.10 \pm 0.02^{\mathrm{a}}$ \\
\hline
\end{tabular}

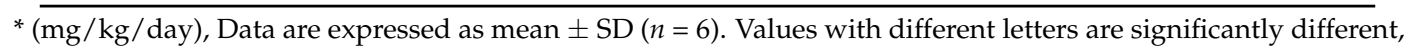
$p<0.05(\mathrm{a}>\mathrm{b})$.

Previous studies have shown that HFD-fed mice demonstrate greater hepatic lipid accumulation [34]. Therefore, we evaluated the effect of SM70EE on lipid accumulation in the liver of mice. Hepatic lipid droplets were identified using oil red $\mathrm{O}$ staining of cryosections. As shown in Figure 4F, lipid droplets were more abundant in HFD-fed control mice than in chow-fed mice, but SM70EE administration prevented excessive lipid accumulation.

\subsection{SM70EE Administration Reduces Blood Lipid Concentrations in HFD-Induced Obese Mice}

We next evaluated the effects of SM70EE supplementation on the concentrations of metabolites associated with glucose and lipid homeostasis in serum samples. It is well known that greater visceral fat accumulation is associated with higher serum TG levels and hyperglycemia in HFD-fed mice [35,36]. As shown in Tables 4 and 5, the concentrations of serum TG and blood glucose were significantly higher in HFD-fed than chow-fed mice. However, SM70EE administration was associated with dramatically lower blood glucose and TG concentrations, indicating that SM70EE can ameliorate the hyperglycemia and hyperlipidemia induced by an HFD. Moreover, obese mice demonstrate higher rates of lipogenesis and cholesterol synthesis, which increase serum cholesterol levels [37]. SM70EE treatment was associated with lower serum concentrations of total cholesterol and LDL-cholesterol compared to treated HFD-fed mice. In addition, obesity is frequently associated with low levels of serum HDL-cholesterol [38], and HDL-cholesterol levels were lower in the HFD-fed group than the chow-fed group (Table 4), but higher in mice administered with SM70EE. Thus, our data suggest that SM70EE can prevent HFD-induced obesity and hyperglycemia. 
Table 4. Effect of supplementation with SM70EE on blood lipid levels in HFD-induced obese mice.

\begin{tabular}{ccccc}
\hline \multirow{2}{*}{ Group } & \multicolumn{3}{c}{ Blood Parameter (mg/dL) } \\
\cline { 2 - 5 } & CHOW & HFD \\
\cline { 2 - 5 } & SM70EE 0 & SM70EE 0 $^{*}$ & SM70EE 150 * $^{*}$ & SM70EE 450 * \\
\hline Triglyceride & $101.6 \pm 32^{\mathrm{b}}$ & $164 \pm 37.2^{\mathrm{a}}$ & $92 \pm 27.3^{\mathrm{b}}$ & $99 \pm 35.2^{\mathrm{b}}$ \\
Total cholesterol & $129.8 \pm 9.9^{\mathrm{b}, \mathrm{c}}$ & $154.5 \pm 14.8^{\mathrm{a}}$ & $119.3 \pm 10.1^{\mathrm{b}, \mathrm{c}}$ & $135.3 \pm 11.8^{\mathrm{b}}$ \\
HDL cholesterol & $120.2 \pm 20.2^{\mathrm{a}}$ & $87.6 \pm 10.4^{\mathrm{c}}$ & $90.8 \pm 9.9^{\mathrm{bc}}$ & $104.9 \pm 7.4^{\mathrm{a}, \mathrm{b}}$ \\
LDL cholesterol & $10.4 \pm 3.6^{\mathrm{b}}$ & $14.6 \pm 4.4^{\mathrm{a}}$ & $7.4 \pm 1.3^{\mathrm{b}}$ & $9.2 \pm 1.3^{\mathrm{b}}$ \\
\hline
\end{tabular}

$*(\mathrm{mg} / \mathrm{kg} /$ day), Data are expressed as mean $\pm \mathrm{SD}(n=6)$. Values with different letters are significantly different, $p<0.05(\mathrm{a}>\mathrm{b}>\mathrm{c})$.

Table 5. Effect of SM70EE treatment on fasting blood glucose level in HFD-induced obese mice for 6 weeks.

\begin{tabular}{|c|c|c|c|c|c|c|c|}
\hline \multirow{2}{*}{ Group } & \multicolumn{7}{|c|}{ Fasting Blood Glucose (mg/dL) } \\
\hline & 0 week & 1 week & 2 week & 3 week & 4 week & 5 week & 6 week \\
\hline CHOW & $124.8 \pm 12.7$ & $136.5 \pm 11.5^{c}$ & $122.5 \pm 15.3^{c}$ & $117.2 \pm 14.3^{\mathrm{b}}$ & $116.7 \pm 18.5^{\mathrm{b}}$ & $107.3 \pm 13.1^{\mathrm{b}}$ & $102.0 \pm 6.4^{\mathrm{c}}$ \\
\hline HFD & $138.2 \pm 18.3$ & $196.3 \pm 17.0^{\mathrm{a}}$ & $180.3 \pm 12.0^{a}$ & $156.0 \pm 39.3^{\mathrm{a}}$ & $158.3 \pm 26.7^{\mathrm{a}}$ & $156.3 \pm 27.5^{\mathrm{a}}$ & $157.5 \pm 16.1^{\mathrm{a}}$ \\
\hline $\begin{array}{c}\text { HFD+ } \\
\text { SM70EE } 150 *\end{array}$ & $141.8 \pm 21.2$ & $173.0 \pm 18.7^{\mathrm{a}, \mathrm{b}}$ & $151.7 \pm 26.6^{b}$ & $138.7 \pm 21.8^{\mathrm{a}, \mathrm{b}}$ & $144.0 \pm 23.7^{\mathrm{a}}$ & $123.7 \pm 17.9^{b}$ & $121.3 \pm 14.1^{b}$ \\
\hline $\begin{array}{c}\text { HFD+ } \\
\text { SM70EE } 450 *\end{array}$ & $129.7 \pm 16.5$ & $155.5 \pm 29.6^{\mathrm{bc}}$ & $150.5 \pm 15.7^{b}$ & $130.2 \pm 17.1^{b}$ & $136.8 \pm 15.5^{\mathrm{a}, \mathrm{b}}$ & $110.3 \pm 18.2^{b}$ & $114.2 \pm 8.6^{b, c}$ \\
\hline
\end{tabular}

$*(\mathrm{mg} / \mathrm{kg} /$ day), Data are expressed as mean $\pm \mathrm{SD}(n=6)$. Values with different letters are significantly different, $p<0.05(\mathrm{a}>\mathrm{b}>\mathrm{c})$.

3.6. Treatment with SM70EE Regulates the Expression of Markers of Adipogenesis and Browning in the WAT of HFD-Fed Mice

To determine whether SM70EE affected adipogenesis in WAT, we analyzed the expression of the key markers of adipogenesis $\mathrm{C} / \mathrm{EBP} \alpha, \operatorname{PPAR} \gamma$, and aP2. As shown in Figure $5 \mathrm{a}$, the expression of these proteins was higher in HFD-fed control mice than in SM70EE-treated mice.
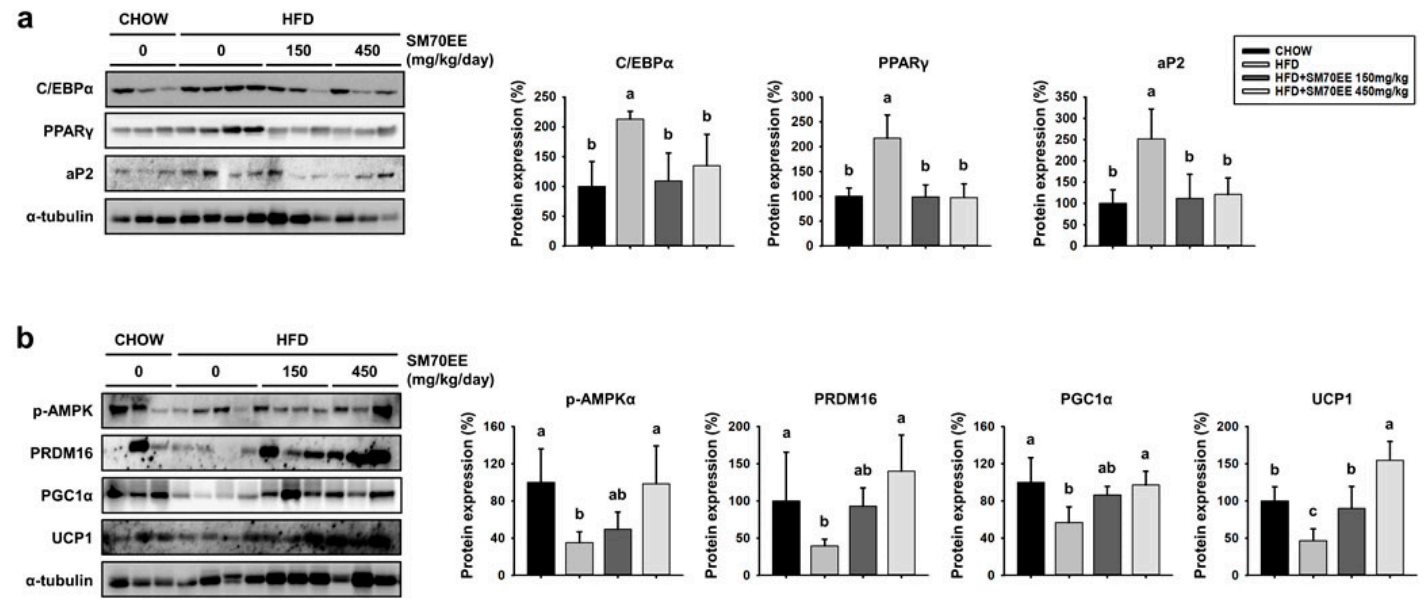

Figure 5. Treatment with SM70EE downregulates markers of adipogenesis and upregulates thermogenic markers in the WAT of HFD-fed mice. WAT from HFD-fed mice administered with SM70EE was analyzed for expression of adipogenic genes (a) and BAT-specific proteins (b). Specific bands were quantified and are presented as graphs. Mice were or were not administered with SM70EE (150 or $450 \mathrm{mg} / \mathrm{kg} /$ day) in their HFD for 6 weeks. Data are presented as mean $\pm \operatorname{SD}(n=6)$. Values with different letters are significantly different, $p<0.05(\mathrm{a}>\mathrm{b}>\mathrm{c})$.

In recent years, studies have shown that activation of AMPK suppresses adipocyte differentiation in 3T3-L1 cells and body weight gain in a diet-induced obese mice model by regulation of key 
adipogenic proteins [16,39]. Moreover, it has been revealed that phosphorylation of AMPK regulates thermogenesis, involving induction of PGC1 $\alpha$ and UCP1 expression [40,41]. We therefore investigated whether SM70EE treatment induced trans-differentiation of white to beige adipocytes as a result of AMPK activation. As shown in Figure 5b, HFD-feeding led to lower levels of phosphorylation of AMPK and lower expression of markers of browning in WAT than were present in chow-fed mice. However, SM70EE treatment resulted in higher protein expression of the key markers of browning PRDM16, PGC1 $\alpha$, and UCP1, which was associated with greater phosphorylation of AMPK. Thus, the lower weight gain in the SM70EE mice appears to be caused by regulating expression of adipogenic and thermogenic proteins.

\subsection{SM70EE Administration Upregulates Thermogenic Genes in the BAT of HFD-Fed Mice and Inducible WAT Cells}

We next wished to determine whether SM70EE treatment induces thermogenic genes not only in WAT, but also in BAT. As shown in Figure 6a, HFD-fed mice showed lower expression of key brown adipocyte-specific proteins in BAT than chow-fed mice. By contrast, SM70EE-treated mice tended to show higher protein expression of crucial BAT markers, such as PRDM16, PGC1 $\alpha$, and UCP1, than HFD-fed control mice. Thus, SM70EE also shows a tendency to activate thermogenesis factors in BAT.
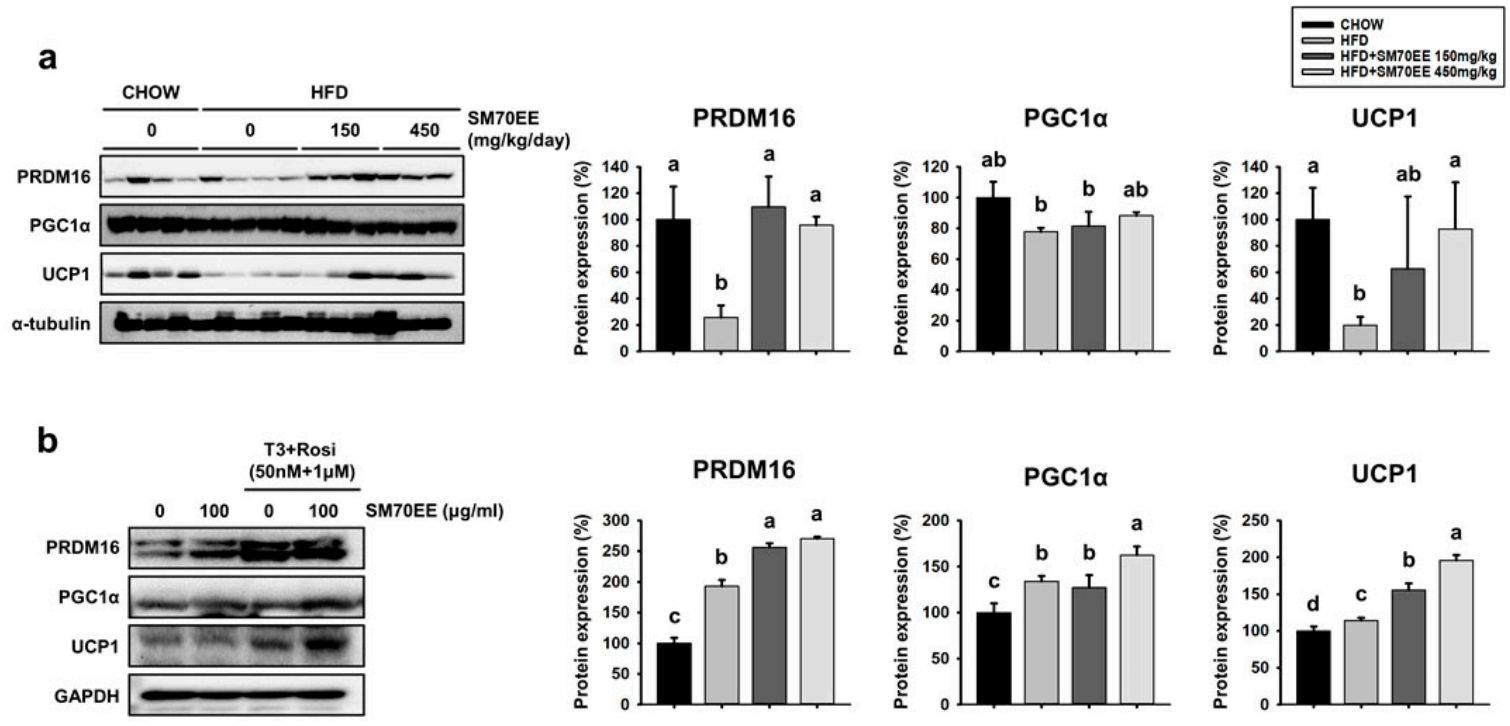

Figure 6. SM70EE administration upregulates thermogenic genes in BAT of HFD-fed mice and in inducible WAT cells. (a) BAT from mice treated with SM70EE was analyzed for the expression of BAT-specific proteins. (b) SVF cells were differentiated into white adipocytes, as described in the Materials and methods. Protein expression of browning factors was measured in primary WAT adipocytes. All data are presented as mean $\pm \operatorname{SD}(n=6)$. Values with different letters are significantly different, $p<0.05$ ( $\mathrm{a}>\mathrm{b}>\mathrm{c}>\mathrm{d}>\mathrm{e})$.

We also wished to investigate whether SM70EE could have browning effects ex vivo. As shown in Figure $6 \mathrm{~b}$, gene expression analysis showed that the presence of triiodothyronine and rosiglitazone induced the expression of PRDM16, PGC1 $\alpha$, and UCP1 more than the differentiation induced using MDI alone. Moreover, the addition of SM70EE led to a greater expression of these markers of BAT than the absence of SM70EE groups in adipose primary cells.

\section{Discussion}

A number of studies have reported that phytochemicals can ameliorate obesity by mechanisms including the downregulation of adipogenesis and upregulation of thermogenesis [42,43]. In this 
study, we have demonstrated that SM70EE, chlorophyll a, and C-phycocyanin reduce lipid droplet accumulation by reducing the expression of adipogenic and lipogenic proteins in 3T3-L1 and C3H10T1/2 cells. Furthermore, we have shown that SM70EE treatment reduces body weight gain and blood lipid concentrations, most likely through downregulation of adipogenic genes. In addition, SM70EE might induce the trans-differentiation of white into brown adipocytes by increasing AMPK phosphorylation and the expression of thermogenic proteins.

In obesity, body weight increases due to accumulation of WAT. This adipose tissue accumulation is caused by both cellular hyperplasia and hypertrophy. Hyperplasia occurs through adipogenesis, in which preadipocytes differentiate into mature adipocytes, secondary to greater transcription of $\mathrm{C} / \mathrm{EBP} \alpha, \mathrm{PPAR} \gamma$, and aP2 [44]. Our results indicate that SM70EE significantly reduces the expression of $\mathrm{C} / \mathrm{EBP} \alpha, \mathrm{PPAR} \gamma$, and aP2 in 3T3-L1 and C3H10T1/2 cells. Expansion of WAT is also facilitated by lipogenesis, involving fatty acid synthesis and TG synthesis [45]. During adipocyte differentiation, SM70EE suppresses the synthesis of TG by reducing the expression of fatty acid and TG synthetic proteins including SREBP1, ACC, FAS, LPAAT $\beta$, lipin1, and DGAT1 in 3T3-L1 and C3H10T1/2 cells. Chlorophyll a and C-phycocyanin also attenuated fat accumulation, but SM70EE had greater anti-obesity effects in these cell types. Thus, our results suggested that consuming whole Spirulina maxima extract, rather than chlorophyll a or C-phycocyanin alone, may have substantial health benefits for people who are overweight or obese. Therefore, we studied the effects of SM70EE in vivo.

Consumption of an HFD increases body weight and fat mass and leads to higher circulating concentrations of TG, total cholesterol, and LDL-cholesterol, and a lower concentration of HDL-cholesterol [46,47]. In addition, hyperglycemia develops, which is a major risk factor for diabetes and other metabolic disorders [48]. Administration of SM70EE to HFD-fed mice for 6 weeks significantly suppressed body weight gain and reduced levels of blood glucose, serum TG, total cholesterol, and LDL-cholesterol, while increasing HDL-cholesterol concentrations. HFD-induced obesity and hyperglycemia has a correlation with hepatic TG accumulation [34,49]. HFD-induced hepatic lipid accumulation was diminished by SM70EE. HFD-induced adipose tissue accumulation is also associated with higher expression of $\mathrm{C} / \operatorname{EBP} \alpha$ and PPAR $\gamma[50,51]$, and we have shown that SM70EE-treated mice express lower levels of the adipogenic proteins $C / \operatorname{EBP} \alpha, \operatorname{PPAR} \gamma$, and aP2 in WAT. Thus, we made consistent findings in vitro and in vivo that imply that SM70EE treatment ameliorates defects associated with obesity.

AMPK $\alpha$ plays a pivotal role in metabolic regulation at the whole body level and in mitochondrial biogenesis [52]. Several studies have demonstrated that activation of AMPK $\alpha$ ameliorates the gain in body weight observed in HFD-induced obesity in mice [53]. For AMPK $\alpha$ to affect the expression of the key factors involved in mitochondrial biogenesis and energy expenditure, PGC- $1 \alpha$ activity is also required [17]. Activation of PGC-1 $\alpha$ induces the expression of PRDM16 and UCP1, the dominant regulator of energy expenditure [54]. UCP1 is a proton transporter that uncouples electron transport from ATP production, thereby enabling energy from the oxidized lipids to be dissipated as heat [55]. UCP1-deficient mice are heavier and have larger fat depots [56], while HFD-fed mice show lower expression of PRDM16 and PGC-1 $\alpha$, which are involved in thermogenesis [57,58]. In this study, we investigated whether SM70EE treatment was associated with AMPK $\alpha$ activation and the expression of markers of browning in WAT and BAT. Here, we have shown that SM70EE administration induces PRDM16 and UCP1 expression alongside AMPK $\alpha$-PGC1 $\alpha$ activation in HFD-fed obese mice. Thus, SM70EE treatment might lead to the differentiation of beige adipocytes by upregulating the expression of proteins of the thermogenic program, including PRDM16, PGC1 $\alpha$, and UCP1 in WAT and BAT. We propose that SM70EE represses obesity-related pathological factors by modulating adipogenesis and thermogenesis genes in HFD-induced obese mice. In addition, we suggest that SM70EE may be more effective than a well-known single compound chlorophyll a or C-phycocyanin with various effects. 


\section{Conclusions}

SM70EE suppresses lipid accumulation by reducing the expression of key adipogenic proteins, such as $\mathrm{C} / \mathrm{EBP} \alpha, \mathrm{PPAR} \gamma$, and aP2, and lipogenic proteins such as SREBP1, ACC, FAS, LPAAT $\beta$, lipin1, and DGAT1, in 3T3-L1 and C3H10T1/2 cells. The index components of SM70EE, chlorophyll a and C-phycocyanin, also inhibited adipogenesis and lipogenesis in 3T3-L1 and C3H10T1/2 cells. Moreover, SM70EE administration reduced body weight gain, fat mass, TG content, and serum total cholesterol in HFD-fed mice, implying an anti-obesity effect of SM70EE. Furthermore, SM70EE-treated HFD-fed mice showed lower expression of adipogenic proteins $(\mathrm{C} / \mathrm{EBP} \alpha, \operatorname{PPAR} \gamma$, and $\mathrm{aP} 2)$ and greater expression of thermogenic factors (PRDM16, PGC1 $\alpha$, and UCP1), which was likely the result of the activation of AMPK $\alpha$. Therefore, our data suggest that SM70EE administration ameliorates HFD-induced obesity by inhibiting adipogenesis and activating the thermogenic expression program.

Author Contributions: Y.-J.S. carried out experiments and wrote the paper; K.-J.K. and B.-Y.L. designed and edited the experiments; J.C. and E.-J.K. participated in data analysis; all authors have read and approved the final manuscript.

Acknowledgments: This research was a part of the project titled 'Development of functional food products with natural materials derived from marine resources', funded by the Ministry of Oceans and Fisheries, Korea. This research was partially supported by the Basic Science Research Program through the National Research Foundation of Korea (NRF), funded by the Ministry of Education (2016R1D1A1A09917209).

Conflicts of Interest: The authors declare no conflict of interest.

\section{References}

1. Jahangir, E.; De Schutter, A.; Lavie, C.J. The relationship between obesity and coronary artery disease. Transl. Res. 2014, 164, 336-344. [CrossRef] [PubMed]

2. Galgani, J.; Ravussin, E. Energy metabolism, fuel selection and body weight regulation. Int. J. Obes. 2008, 32 (Suppl. 7), S109-S119. [CrossRef] [PubMed]

3. Ramsay, T.G. Fat cells. Endocrinol. Metab. Clin. N. Am. 1996, 25, 847-870. [CrossRef]

4. Tseng, Y.H.; Kokkotou, E.; Schulz, T.J.; Huang, T.L.; Winnay, J.N.; Taniguchi, C.M.; Tran, T.T.; Suzuki, R.; Espinoza, D.O.; Yamamoto, Y.; et al. New role of bone morphogenetic protein 7 in brown adipogenesis and energy expenditure. Nature 2008, 454, 1000-1004. [CrossRef] [PubMed]

5. Gesta, S.; Tseng, Y.H.; Kahn, C.R. Developmental origin of fat: Tracking obesity to its source. Cell 2007, 131, 242-256. [CrossRef] [PubMed]

6. Nedergaard, J.; Cannon, B. The browning of white adipose tissue: Some burning issues. Cell Metab. 2014, 20, 396-407. [CrossRef] [PubMed]

7. Harms, M.; Seale, P. Brown and beige fat: Development, function and therapeutic potential. Nat. Med. 2013, 19, 1252-1263. [CrossRef] [PubMed]

8. Cowherd, R.M.; Lyle, R.E.; McGehee, R.E., Jr. Molecular regulation of adipocyte differentiation. Semin. Cell Dev. Biol. 1999, 10, 3-10. [CrossRef] [PubMed]

9. Ranganathan, G.; Unal, R.; Pokrovskaya, I.; Yao-Borengasser, A.; Phanavanh, B.; Lecka-Czernik, B.; Rasouli, N.; Kern, P.A. The lipogenic enzymes DGAT1, FAS, and LPL in adipose tissue: Effects of obesity, insulin resistance, and TZD treatment. J. Lipid Res. 2006, 47, 2444-2450. [CrossRef] [PubMed]

10. Takeuchi, K.; Reue, K. Biochemistry, physiology, and genetics of GPAT, AGPAT, and lipin enzymes in triglyceride synthesis. Am. J. Physiol. Endocrinol. Metab. 2009, 296, E1195-E1209. [CrossRef] [PubMed]

11. Shi, Y.; Cheng, D. Beyond triglyceride synthesis: The dynamic functional roles of MGAT and DGAT enzymes in energy metabolism. Am. J. Physiol. Endocrinol. Metab. 2009, 297, E10-E18. [CrossRef] [PubMed]

12. Lenhard, J.M. Lipogenic enzymes as therapeutic targets for obesity and diabetes. Curr. Pharm. Des. 2011, 17, 325-331. [CrossRef] [PubMed]

13. Phan, J.; Peterfy, M.; Reue, K. Lipin expression preceding peroxisome proliferator-activated receptor-gamma is critical for adipogenesis in vivo and in vitro. J. Biol. Chem. 2004, 279, 29558-29564. [CrossRef] [PubMed]

14. Gale, S.E.; Frolov, A.; Han, X.; Bickel, P.E.; Cao, L.; Bowcock, A.; Schaffer, J.E.; Ory, D.S. A regulatory role for 1-acylglycerol-3-phosphate-o-acyltransferase 2 in adipocyte differentiation. J. Biol. Chem. 2006, 281, 11082-11089. [CrossRef] [PubMed] 
15. Zhou, Y.; Wang, D.; Zhu, Q.; Gao, X.; Yang, S.; Xu, A.; Wu, D. Inhibitory effects of A-769662, a novel activator of AMP-activated protein kinase, on 3T3-L1 adipogenesis. Biol. Pharm. Bull. 2009, 32, 993-998. [CrossRef] [PubMed]

16. Giri, S.; Rattan, R.; Haq, E.; Khan, M.; Yasmin, R.; Won, J.S.; Key, L.; Singh, A.K.; Singh, I. AICAR inhibits adipocyte differentiation in 3T3L1 and restores metabolic alterations in diet-induced obesity mice model. Nutr. Metab. 2006, 3, 31. [CrossRef] [PubMed]

17. Jager, S.; Handschin, C.; St-Pierre, J.; Spiegelman, B.M. AMP-activated protein kinase (AMPK) action in skeletal muscle via direct phosphorylation of PGC-1alpha. Proc. Natl. Acad. Sci. USA 2007, 104, 12017-12022. [CrossRef] [PubMed]

18. Canto, C.; Auwerx, J. PGC-1alpha, SIRT1 and AMPK, an energy sensing network that controls energy expenditure. Curr. Opin. Lipidol. 2009, 20, 98-105. [CrossRef] [PubMed]

19. Bonet, M.L.; Oliver, P.; Palou, A. Pharmacological and nutritional agents promoting browning of white adipose tissue. Biochim. Biophys. Acta 2013, 1831, 969-985. [CrossRef] [PubMed]

20. Miranda, M.S.; Cintra, R.G.; Barros, S.B.; Mancini Filho, J. Antioxidant activity of the microalga Spirulina maxima. Braz. J. Med. Biol. Res. 1998, 31, 1075-1079. [CrossRef] [PubMed]

21. Abd El-Baky, H.H.; El-Baroty, G.S. Characterization and bioactivity of phycocyanin isolated from Spirulina maxima grown under salt stress. Food Funct. 2012, 3, 381-388. [CrossRef] [PubMed]

22. Choi, W.Y.; Lee, H.Y. Effect of ultrasonic extraction on production and structural changes of C-phycocyanin from marine Spirulina maxima. Int. J. Mol. Sci. 2018, 19, 220. [CrossRef] [PubMed]

23. Choi, W.Y.; Lee, H.Y. Enhancement of chlorophyll a production from marine Spirulina maxima by an optimized ultrasonic extraction process. Appl. Sci. 2017, 8, 26. [CrossRef]

24. Koh, E.J.; Seo, Y.J.; Choi, J.; Lee, H.Y.; Kang, D.H.; Kim, K.J.; Lee, B.Y. Spirulina maxima extract prevents neurotoxicity via promoting activation of BDNF/CREB signaling pathways in neuronal cells and mice. Molecules 2017, 22, 1363. [CrossRef] [PubMed]

25. Koh, E.-J.; Kim, K.-J.; Choi, J.; Kang, D.-H.; Lee, B.-Y. Spirulina maxima extract prevents cell death through BDNF activation against amyloid beta 1-42 (Aß1-42) induced neurotoxicity in PC12 cells. Neurosci. Lett. 2018, 673, 33-38. [CrossRef] [PubMed]

26. Oh, S.H.; Ahn, J.; Kang, D.H.; Lee, H.Y. The effect of ultrasonificated extracts of Spirulina maxima on the anticancer activity. Mar. Biotechnol. 2011, 13, 205-214. [CrossRef] [PubMed]

27. Chamorro, G.; Perez-Albiter, M.; Serrano-Garcia, N.; Mares-Samano, J.J.; Rojas, P. Spirulina maxima pretreatment partially protects against 1-methyl-4-phenyl-1,2,3,6-tetrahydropyridine neurotoxicity. Nutr. Neurosci. 2006, 9, 207-212. [CrossRef] [PubMed]

28. Subramoniam, A.; Asha, V.V.; Nair, S.A.; Sasidharan, S.P.; Sureshkumar, P.K.; Rajendran, K.N.; Karunagaran, D.; Ramalingam, K. Chlorophyll revisited: Anti-inflammatory activities of chlorophyll a and inhibition of expression of TNF-alpha gene by the same. Inflammation 2012, 35, 959-966. [CrossRef] [PubMed]

29. Romay, C.; Armesto, J.; Remirez, D.; Gonzalez, R.; Ledon, N.; Garcia, I. Antioxidant and anti-inflammatory properties of C-phycocyanin from blue-green algae. Inflamm. Res. 1998, 47, 36-41. [CrossRef] [PubMed]

30. Ou, Y.; Lin, L.; Yang, X.; Pan, Q.; Cheng, X. Antidiabetic potential of phycocyanin: Effects on KKAy mice. Pharm. Biol. 2013, 51, 539-544. [CrossRef] [PubMed]

31. Aune, U.L.; Ruiz, L.; Kajimura, S. Isolation and differentiation of stromal vascular cells to beige/brite cells. J. Vis. Exp. 2013. [CrossRef]

32. Bennett, M.K.; Lopez, J.M.; Sanchez, H.B.; Osborne, T.F. Sterol regulation of fatty acid synthase promoter. Coordinate feedback regulation of two major lipid pathways. J. Biol. Chem. 1995, 270, 25578-25583. [CrossRef] [PubMed]

33. Sekiya, M.; Yahagi, N.; Matsuzaka, T.; Takeuchi, Y.; Nakagawa, Y.; Takahashi, H.; Okazaki, H.; Iizuka, Y.; Ohashi, K.; Gotoda, T.; et al. SREBP-1-independent regulation of lipogenic gene expression in adipocytes. J. Lipid Res. 2007, 48, 1581-1591. [CrossRef] [PubMed]

34. Carmiel-Haggai, M.; Cederbaum, A.I.; Nieto, N. A high-fat diet leads to the progression of non-alcoholic fatty liver disease in obese rats. FASEB J. 2005, 19, 136-138. [CrossRef] [PubMed]

35. Yeap, B.B.; Chubb, S.A.; Flicker, L.; McCaul, K.A.; Ebeling, P.R.; Beilby, J.P.; Norman, P.E. Reduced serum total osteocalcin is associated with metabolic syndrome in older men via waist circumference, hyperglycemia, and triglyceride levels. Eur. J. Endocrinol. 2010, 163, 265-272. [CrossRef] [PubMed] 
36. Katsuki, A.; Sumida, Y.; Urakawa, H.; Gabazza, E.C.; Murashima, S.; Maruyama, N.; Morioka, K.; Nakatani, K.; Yano, Y.; Adachi, Y. Increased visceral fat and serum levels of triglyceride are associated with insulin resistance in japanese metabolically obese, normal weight subjects with normal glucose tolerance. Diabetes Care 2003, 26, 2341-2344. [CrossRef] [PubMed]

37. Zomzely, C.; Mayer, J. Levels of serum cholesterol in obese mice. Nature 1958, 182, 1738-1739. [CrossRef] [PubMed]

38. Arai, T.; Yamashita, S.; Hirano, K.; Sakai, N.; Kotani, K.; Fujioka, S.; Nozaki, S.; Keno, Y.; Yamane, M.; Shinohara, E.; et al. Increased plasma cholesteryl ester transfer protein in obese subjects. A possible mechanism for the reduction of serum hdl cholesterol levels in obesity. Arterioscler. Thromb. 1994, 14, 1129-1136. [CrossRef] [PubMed]

39. Habinowski, S.A.; Witters, L.A. The effects of AICAR on adipocyte differentiation of 3T3-L1 cells. Biochem. Biophys. Res. Commun. 2001, 286, 852-856. [CrossRef] [PubMed]

40. Wan, Z.; Root-McCaig, J.; Castellani, L.; Kemp, B.E.; Steinberg, G.R.; Wright, D.C. Evidence for the role of ampk in regulating PGC-1 alpha expression and mitochondrial proteins in mouse epididymal adipose tissue. Obesity 2014, 22, 730-738. [CrossRef] [PubMed]

41. Bostrom, P.; Wu, J.; Jedrychowski, M.P.; Korde, A.; Ye, L.; Lo, J.C.; Rasbach, K.A.; Bostrom, E.A.; Choi, J.H.; Long, J.Z.; et al. A PGC1-alpha-dependent myokine that drives brown-fat-like development of white fat and thermogenesis. Nature 2012, 481, 463-468. [CrossRef] [PubMed]

42. Cypess, A.M.; Kahn, C.R. Brown fat as a therapy for obesity and diabetes. Curr. Opin. Endocrinol. Diabetes Obes. 2010, 17, 143-149. [CrossRef] [PubMed]

43. Choi, J.; Kim, K.J.; Koh, E.J.; Lee, B.Y. Gelidium elegans regulates the AMPK-PRDM16-UCP-1 pathway and has a synergistic effect with orlistat on obesity-associated features in mice fed a high-fat diet. Nutrients 2017, 9, 342. [CrossRef] [PubMed]

44. Camp, H.S.; Ren, D.; Leff, T. Adipogenesis and fat-cell function in obesity and diabetes. Trends Mol. Med. 2002, 8, 442-447. [CrossRef]

45. Moreno-Indias, I.; Tinahones, F.J. Impaired adipose tissue expandability and lipogenic capacities as ones of the main causes of metabolic disorders. J. Diabetes Res. 2015, 2015, 970375. [CrossRef] [PubMed]

46. Torre-Villalvazo, I.; Tovar, A.R.; Ramos-Barragan, V.E.; Cerbon-Cervantes, M.A.; Torres, N. Soy protein ameliorates metabolic abnormalities in liver and adipose tissue of rats fed a high fat diet. J. Nutr. 2008, 138, 462-468. [CrossRef] [PubMed]

47. Kalaivanisailaja, J.; Manju, V.; Nalini, N. Lipid profile in mice fed a high-fat diet after exogenous leptin administration. Pol. J. Pharmacol. 2003, 55, 763-769. [PubMed]

48. Ikemoto, S.; Takahashi, M.; Tsunoda, N.; Maruyama, K.; Itakura, H.; Ezaki, O. High-fat diet-induced hyperglycemia and obesity in mice: Differential effects of dietary oils. Metabolism 1996, 45, 1539-1546. [CrossRef]

49. Cotter, D.G.; Ercal, B.; Huang, X.; Leid, J.M.; d'Avignon, D.A.; Graham, M.J.; Dietzen, D.J.; Brunt, E.M.; Patti, G.J.; Crawford, P.A. Ketogenesis prevents diet-induced fatty liver injury and hyperglycemia. J. Clin. Investig. 2014, 124, 5175-5190. [CrossRef] [PubMed]

50. Kubota, N.; Terauchi, Y.; Miki, H.; Tamemoto, H.; Yamauchi, T.; Komeda, K.; Satoh, S.; Nakano, R.; Ishii, C.; Sugiyama, T.; et al. PPAR gamma mediates high-fat diet-induced adipocyte hypertrophy and insulin resistance. Mol. Cell 1999, 4, 597-609. [CrossRef]

51. Jones, J.R.; Barrick, C.; Kim, K.A.; Lindner, J.; Blondeau, B.; Fujimoto, Y.; Shiota, M.; Kesterson, R.A.; Kahn, B.B.; Magnuson, M.A. Deletion of PPARgamma in adipose tissues of mice protects against high fat diet-induced obesity and insulin resistance. Proc. Natl. Acad. Sci. USA 2005, 102, 6207-6212. [CrossRef] [PubMed]

52. Kahn, B.B.; Alquier, T.; Carling, D.; Hardie, D.G. AMP-activated protein kinase: Ancient energy gauge provides clues to modern understanding of metabolism. Cell Metab. 2005, 1, 15-25. [CrossRef] [PubMed]

53. Lindholm, C.R.; Ertel, R.L.; Bauwens, J.D.; Schmuck, E.G.; Mulligan, J.D.; Saupe, K.W. A high-fat diet decreases AMPK activity in multiple tissues in the absence of hyperglycemia or systemic inflammation in rats. J. Physiol. Biochem. 2013, 69, 165-175. [CrossRef] [PubMed]

54. Seale, P.; Bjork, B.; Yang, W.; Kajimura, S.; Chin, S.; Kuang, S.; Scime, A.; Devarakonda, S.; Conroe, H.M.; Erdjument-Bromage, H.; et al. PRDM16 controls a brown fat/skeletal muscle switch. Nature 2008, 454, 961-967. [CrossRef] [PubMed] 
55. Cannon, B.; Nedergaard, J. Brown adipose tissue: Function and physiological significance. Physiol. Rev. 2004, 84, 277-359. [CrossRef] [PubMed]

56. Feldmann, H.M.; Golozoubova, V.; Cannon, B.; Nedergaard, J. UCP1 ablation induces obesity and abolishes diet-induced thermogenesis in mice exempt from thermal stress by living at thermoneutrality. Cell Metab. 2009, 9, 203-209. [CrossRef] [PubMed]

57. Coulter, A.A.; Bearden, C.M.; Liu, X.; Koza, R.A.; Kozak, L.P. Dietary fat interacts with QTLs controlling induction of PGC-1 alpha and UCP1 during conversion of white to brown fat. Physiol. Genom. 2003, 14, 139-147. [CrossRef] [PubMed]

58. Arcari, D.P.; Bartchewsky, W.; dos Santos, T.W.; Oliveira, K.A.; Funck, A.; Pedrazzoli, J.; de Souza, M.F.; Saad, M.J.; Bastos, D.H.; Gambero, A.; et al. Antiobesity effects of yerba mate extract (ilex paraguariensis) in high-fat diet-induced obese mice. Obesity 2009, 17, 2127-2133. [CrossRef] [PubMed]

C 2018 by the authors. Licensee MDPI, Basel, Switzerland. This article is an open access article distributed under the terms and conditions of the Creative Commons Attribution (CC BY) license (http://creativecommons.org/licenses/by/4.0/). 